\title{
EXTENDED EXCHANGE TRANSFUSION IN PRE-HYDROPIC INFANTS
}

\author{
BY \\ EILEEN M. O'NEILL and RONALD R. GORDON \\ From the City General Hospital, Sheffield
}

(RECEIVED FOR PUBLICATION AUGUST 5, 1958)

Exchange transfusion in the immediate treatment of haemolytic disease of the newborn is now a fully established procedure with more or less agreed indications for its use (Allen and Diamond, 1957). Up till now the procedure has been mainly used to prevent kernikterus and in this it has been eminently successful both in the 'clinical' and the 'pathological' varieties of this condition. It can be said that in any unit in which facilities for proper exchange transfusion are available kernikterus should no longer be a problem in haemolytic disease due either to Rhesus, ABO or other incompatibility.

The deaths still encountered in haemolytic disease of the newborn are of two types: those which occur in utero resulting in stillbirth and those in which the babies are born alive but die within a few hours either before, during, or after the first exchange transfusion. The main cause of death in the first type is hydrops foetalis, which is essentially severe heart failure occurring in utero; in the second type the cause of death is probably also heart failure so that the term 'pre-hydrops' would be a fairly accurate description of this clinical condition. It is mainly with this group of pre-hydropic infants that we are concerned in this communication.

Before discussing this group further, however, we must explain that in our view these deaths are in quite a different category from those described by Campbell (1955). In his cases the babies were relatively mildly affected and it was only because of the fear of later jaundice that an exchange was undertaken. In them the babies were perfectly well until they suddenly collapsed and it was felt that there was probably a severe biochemical upset affecting perhaps the serum potassium (Campbell, 1955) or serum citrate (Kelsall and Vos, 1955). We have been fortunate in having no experience of this type of case and it seems that no satisfactory explanation for them is, as yet, forthcoming (Farquhar and Smith, 1958).
In contrast, the pre-hydropic babies are born with a low cord haemoglobin (under $10 \mathrm{~g}$. \%) and are clinically pale and either not jaundiced or only mildly so. The cord blood bilirubin is usually high and may be very high. In addition, the babies are usually ill with rapid respirations which often become grunting in character and there is often some oedema. The liver and spleen are both enlarged and there is sometimes a profuse purpura. The fact that haemolysis is proceeding rapidly is shown by the high reticulocyte count in the cord blood. These babies are on the verge of, or in, heart failure (Mollison and Cutbush, 1949), as is shown by the high venous pressure recorded when the catheter is passed up the umbilical vein. Even with the use of exchange transfusion the mortality in this group is still high.

The occurrence of pre-hydropic infants is well documented in the literature and they are usually shown as dying from heart failure. In the report of Mollison and Walker (1952), out of 79 deaths during the first week of life 17 were due to this cause: eight of these died in spite of treatment by simple or exchange transfusion. Walker and Neligan (1955) in their own series of 250 treated cases of haemolytic disease, reported deaths attributable to the disease and, of these, five were due to heart failure, comprising the largest single cause of death. Walker and Mollison (1957), recently reviewed the deaths from the disease in England and Wales and reported that in two years (1953 and 1955), there were 312 and 315 deaths respectively: of these, 58 and 55 were attributed to heart failure although all of them did not necessarily have ' proper' treatment. In fact, of these 113 infants, in only 75 was exchange transfusion attempted, 57 of them dying during the procedure. They reported a further group of 69 infants in the two years who were said to die of ' hydrops foetalis', this is probably the severest degree of the condition we are discussing and, in 
our view, it is not of necessity fatal. We feel that the name 'hydrops' should be kept only as a pathological term since it has, by usage, an implication of death or impending death; the name, ' pre-hydrops' could then be applied to all those born alive who show any of the signs of heart failure. If one includes the cases in Walker and Mollison's (1957) series which were classified as born alive "with hydrops ', out of a total of 627 deaths in two years, $182(113+69)$ were attributed to heart failure; in the same period 187 were attributed to kernikterus. The deaths from kernikterus are likely to decrease further with the years so that heart failure as a cause of death will become relatively more important. The management of these infants is still a difficult problem (Walker and Neligan, 1955).

It is usually recommended that the cord be clamped early and that before starting exchange transfusion blood should be taken off so as to reduce the venous pressure. The amount varies between $20 \mathrm{ml}$. and $80 \mathrm{ml}$. It has also been suggested that instead of taking it off all at once a larger amount of blood should be removed than is transfused in the early stages of the exchange until a suitable 'venesection' has been achieved (Walker and Neligan, 1955). It is not often stressed, however, that it may be difficult and even dangerous to reduce the venous pressure and that even when reduced it may rise again during the subsequent exchange transfusion: yet most paediatricians know this and also that accurate measurements of the venous pressure are difficult to record especially at the start of the transfusion.

It has also been suggested (Murray and Norman, 1957) that digitalis should be given to reduce the venous pressure, but if this is followed by ordinary exchange transfusion it seems likely that quite a proportion of the drug will be removed before becoming effective (Wheeler and Ambuel, 1957). It could, however, be a useful adjuvant in the treatment: it was not used in either of the two recent severe cases we now report who died, nor in the third case which recovered.

\section{Case Histories}

Case 1. S.B. was the second affected child in the family, and the estimated maturity was 36 weeks. Delivery was normal, and the cord clamped immediately. Birth weight was $5 \mathrm{lb}$. $5 \mathrm{oz}$. The cord blood showed a positive Coombs test: $\mathrm{Hb} 42 \%(6 \cdot 3 \mathrm{~g}$. \%); serum bilirubin $12 \mathrm{mg}$. \%; reticulocyte count $50 \%$. From the start the baby was ill, grunting and cyanosed, although there was no oedema and no purpura. Exchange transfusion by the umbilical route was started two hours after delivery and the venous pressure was found to be high, the blood gushing round the catheter making accurate measurement impossible. A further $20 \mathrm{ml}$. were removed after the catheter was in position and the venous pressure was then normal. The exchange consisted of $540 \mathrm{ml}$. in and $560 \mathrm{ml}$. out. The blood used was three days old. The time taken was 60 minutes. On completion the venous pressure had risen to $15 \mathrm{~cm}$. of blood, and just afterwards the baby became suddenly more cyanosed, gasped a few times, and died. A posttransfusion specimen of the baby's blood showed a potassium level of only $21.1 \mathrm{mg}$. $\%(5.9 \mathrm{mEq} / 1$.$) .$ Autopsy showed dilatation of the right ventricle but nothing else.

Case 2. K.T. was the second affected child in the family, the previous one having hydrops foetalis. The estimated maturity was 39 weeks. There was antepartum haemorrhage due to type 2 placenta praevia. A.R.M. was performed and the delivery was uneventful. Birth weight was $6 \mathrm{lb}$. The cord was clamped immediately. Cord blood results showed a positive Coombs test: $\mathrm{Hb} 30 \%$ (4.2 g. \%); bilirubin $4.6 \mathrm{mg}$. $\%$; reticulocytes $52 \%$.

The child's general condition from the start was poor: there was extreme pallor and slight jaundice; the respirations were grunting; there were many petechiae but no oedema. Exchange transfusion was started one hour and 50 minutes after birth. Once again the venous pressure was high and was brought down to normal by the removal of $50 \mathrm{ml}$. of blood. An exchange of $350 \mathrm{ml}$. was then effected; at first the baby's general condition improved but the transfusion had to be stopped at the above level because of a sudden deterioration 36 minutes after starting. At this stage the venous pressure had risen to $20 \mathrm{~cm}$. although it was normal before starting the exchange proper. Despite calcium gluconate and coramine the baby died and once again the cause of death at autopsy appeared to be heart failure. Two bottles of blood were involved in this exchange, the first being one day old and the second six days old.

These two babies were born exceedingly anaemic and very ill. They were both in heart failure and in both the high venous pressure was relieved before the exchange was started. Even so the failure was progressive, resulting in a further rise of venous pressure throughout the exchange and terminating in death. We felt, therefore, that this method was not entirely satisfactory although we realized that infants just as severely affected had been treated similarly with recovery (Watson, Crosse and Hatchuel, 1954; Walker and Neligan, 1955). We felt that, since in other forms of chronic anaemia, rapid transfusion may kill the patient (SharpeySchafer, 1945), too rapid exchange transfusion might also do so, especially as we had evidence of a rise in venous pressure during the exchange. It seemed possible, therefore, that if we removed a considerable amount of blood to relieve venous pressure we could replace it by means of a 
slow drip in the same way as for any other chronic anaemia; during the procedure also the pressure could be watched and if it increased further then another venesection could be performed. This involved being prepared to leave the catheter in position for a prolonged period but this, of course, has been done previously in the treatment of anuria without harm (Russell, Dewhurst and Brace, 1954). In such critically ill infants we felt that it was completely justified to do so, although we fully agree with Wheeler and Ambuel (1957) that a catheter should not be left in the umbilical vein for several days just because a repeat exchange might be necessary.

When Case 3 was seen we had the opportunity to try out this system of what might be called 'extended exchange transfusion'.

Case 3. P.P. was the first affected child in the family. There was slight A.P.H. at 30 weeks, but a normal fullterm delivery. Birth weight was $8 \mathrm{lb}$. 20z. and the cord was clamped immediately. Cord blood showed a positive Coombs test: $\mathrm{Hb} 40 \%(5.9 \mathrm{~g} . \%)$, bilirubin $14 \mathrm{mg} . \%$ and reticulocytes $40 \%$. At birth the baby was very pale and slightly jaundiced; there was no oedema and no bleeding. Respirations were rapid and shallow and there was some cyanosis. Whilst waiting for the blood to be prepared the condition became even worse and the respirations became grunting in character. It was, therefore, decided to perform a slower form of exchange transfusion to try and avoid the disappointments of the previous two cases.

At the age of $2 \frac{1}{2}$ hours the transfusion was started via the umbilical route. Again the venous pressure was found to be exceedingly high and so, in spite of the severe anaemia, $100 \mathrm{ml}$. of blood were withdrawn with marked clinical improvement as well as improvement in the venous pressure, although even then it did not come down completely to normal. On this occasion, instead of proceeding to the complete exchange following the venesection, a transfusion of suitable blood was allowed to run into the umbilical vein very slowly over the'next eight hours. During this time the baby received $200 \mathrm{ml}$. of blood which was a little more than we had anticipated. At this stage the baby was becoming dyspnoeic again so a further $60 \mathrm{ml}$. of blood were withdrawn with considerable improvement both clinically and in the venous pressure. From this point onwards further amounts of blood were removed at intervals whilst the slow drip was continued until the anaemia was fully corrected and the baby was out of failure. From then on small amounts of blood were removed and transfused at the same sitting and eventually it was felt safe to perform a complete exchange to remove the circulating bilirubin which had reached $16 \mathrm{mg}$. \%. A summary of the treatment, which was certainly fully ' extended', is given in the accompanying appendix. It can be seen that the process lasted 63 hours.

In addition to the usual warmth, oxygen, calcium gluconate and vitamin $\mathrm{K}$, intramuscular penicillin and streptomycin were given from the first day as a prophylactic. A final blood sample, taken at the end of the transfusion, grew only coagulase negative staphylococci in one bottle: the serum calcium at that time was $9.2 \mathrm{mg}$. \% (4.6 mEq/1.), the potassium was $13.0 \mathrm{mg}$. \% (3.3 mEq/1.) and the serum bilirubin $9.0 \mathrm{mg} . \%$.

Progress was slow and the baby was feeble and moderately jaundiced for 15 days. The liver remained enlarged and the skin became 'sclerematous'. Slowly she improved, however, but it was three weeks after her birth before she was fit enough to go home. Since then progress has been perfectly satisfactory.

\section{Discussion}

We appreciate that this infant could have survived with ordinary exchange transfusion, as has been reported before (Watson et al., 1954; Walker and Neligan, 1955). We do not think that the method used has not in some way been used previously since it may differ only slightly from the 'leisurely' exchange referred to by Farquhar and Smith (1958), and of course many people have probably left the catheter in position for lengthy periods.

On the other hand we believe that the idea of leaving the catheter in and performing the exchange gradually in the way described is a reasonable method to use in certain cases.

In retrospect, we think that in our Case 3 we probably removed and replaced too much blood in the first stage and in future would aim at $50 \mathrm{ml}$. amounts in and out unless the venous pressure was so high that clinical improvement could not be obtained except by greater venesection. We would probably make use of digitalis in further cases also since it might have time to become effective. The aim of treatment at this stage is to bring the patient out of heart failure as quickly as possible. Once immediate improvement has been obtained the anaemia should be corrected fairly slowly by means of a drip transfusion; removal and replacement, by slow drip, can then be continued until the baby is completely out of heart failure. Only then should any real attempt be made to remove the infant's red cells, and this, as well as the reduction in the serum bilirubin, can be effected by repeated exchange transfusions. In our case it took about 48 hours to correct the venous pressure and the anaemia and by that time the height of the serum bilirubin called for a full exchange. As a result a much greater volume of blood than usual was required to treat this infant and a total of $1,650 \mathrm{ml}$. was used.

It is possible that in the future some extended exchange technique, if found to be of value, may be more often required since it seems possible that more of these severely affected babies may be seen. 
It was shown by Watson et al. (1954) that in families with a bad history better results might be obtained by early induction of labour with immediate exchange transfusion of the premature baby, than by leaving the pregnancy to continue and result in stillbirth. The idea of premature induction of labour in sensitized women has also recently been advocated by Kelsall, Vos and Kirk (1958). The main reason why premature induction was so strongly condemned by Mollison and Walker (1952) was because of the high incidence of kernikterus in the resulting premature babies. As Walker et al. (1957) indicate, it is unlikely that this high incidence of kernikterus would occur today owing to the much greater use of repeated exchange transfusion. For this reason early induction does not now hold the same terrors as it did and it seems likely that it will be more fully used in the future, especially if a means can be found to determine when the foetus is severely affected. The objective then will be to convert a hydropic baby which dies in utero into a pre-hydropic one with a chance of survival. We believe that in the management of these very ill infants extended exchange transfusion may be found to be of value.

\section{Summary}

The term 'pre-hydrops' as applied to some babies suffering from haemolytic disease of the newborn is described.

A method of treating such babies by means of an extended exchange transfusion is given, with details in a single case.

\section{REFERENCES}

Allen, F. H. and Diamond, L. K. (1957). New Engl. J. Med., 257, Campbell, W. A. B. (1955). Arch. Dis. Childh., 30, 513.

Farquhar, J. W. and Smith, H. (1958). Ibid., 33, 142.

Kelsall, G. A. and Vos, G. H. (1955). Ibid., 2, 161.

, and Kirk, R. L. (1958). Brit. med. J., 2, 468.

Mollison, P L. and Cutbush, M. (1949). Brit. med. J., 1, 123

- and Walker, W. (1952). Lancet, 1, 429.

Murray, J. and Norman, A. P. (1957). Proc. roy Soc. Med., 50, 711.

Russell, C. S., Dewhurst, C. J. and Brace, J. C. (1954). Lancet, 1, 902.

Sharpey-Schafer, E. P. (1945). Lancet, 2, 296

Walker, W. and Mollison, P. L. (1957). Ibid., 1, 1309.
Walker, W., Murray, S. and Russell, J. K. (1957). J. Obstet. Gynaec. Brit. Emp., 64, 573.

- and Neligan, G. A. (1955). Brit. med. J., 1, 681

Watson, H. B., Crosse, V. M. and Hatchuel, W. L. F. (1954). Ibid., 1, 679.

Wheeler, W. E. and Ambuel, J. P. (1957). Pediat. Clin. N. Amer., 4, 383 .

\section{APPENDIX}

\section{Summary of Extended Exchange Transfusion}

9.3.58. 11.5 p.m. Born. $\mathrm{Hb} \quad 40 \%$. Bilirubin $14.0 \mathrm{mg} . \%$.

10.3.58. 1.30 a.m. Exchange transfusion started. Venous pressure very high. $100 \mathrm{ml}$. blood withdrawn followed by slow drip of partly packed red cells.

10.50 a.m. Venous pressure high. $60 \mathrm{ml}$. blood withdrawn and drip continued. Total blood in $200 \mathrm{ml}$. Total blood out $160 \mathrm{ml}$.

6.50 p.m. Venous pressure high. $50 \mathrm{ml}$. blood withdrawn. Total blood out $210 \mathrm{ml}$. Total blood in $259 \mathrm{ml}$. Drip continued.

$11.50 \mathrm{p.m}$. Venous pressure normal. $50 \mathrm{ml}$. blood withdrawn followed by exchange of $30 \mathrm{ml}$. Total blood out $290 \mathrm{ml}$. Total blood in $339 \mathrm{ml}$. Drip continued.

11.3.58. 9.30 a.m. Hb $108 \%$. Bilirubin $15 \mathrm{mg}$. \%. Venous pressure normal. $50 \mathrm{ml}$. blood withdrawn followed by exchange of $50 \mathrm{ml}$. Total blood out $390 \mathrm{ml}$. Total blood in $576 \mathrm{ml}$. Drip continued.

5.38 p.m. Venous pressure normal. $60 \mathrm{ml}$. blood withdrawn followed by exchange of $210 \mathrm{ml}$. Total blood out $660 \mathrm{ml}$. Total blood in $895 \mathrm{ml}$. Drip continued.

11.30 p.m. $50 \mathrm{ml}$. blood withdrawn. Total blood out $710 \mathrm{ml}$. Total blood in $931 \mathrm{ml}$. Drip continued.

12.3.58. 10.15 a.m. Hb $104 \%$. Bilirubin $16.0 \mathrm{mg}$. \% . $10 \mathrm{ml}$. blood withdrawn. Total blood out $720 \mathrm{ml}$. Total blood in $978 \mathrm{ml}$. Drip continued.

2.15 p.m. $40 \mathrm{ml}$. blood withdrawn followed by exchange of $640 \mathrm{ml}$. Total blood out $1,400 \mathrm{ml}$. Total blood in $1,650 \mathrm{ml}$. Drip stopped.

13.3.58. Hb $110 \%$. Bilirubin $9.0 \mathrm{mg}$. \% .

26.3.58. $\mathrm{Hb} 77 \%$. Bilirubin $2 \cdot 0 \mathrm{mg}$. $\%$. 